\title{
Upaya Penguatan Manajemen Pemasaran Hasil Perikanan Berbasis Media Online di TPI Sendangbiru, Kabupaten Malang, Indonesia
}

\author{
1,2* Dian Aliviyanti, ${ }^{1,2}$ Bambang Semedi, ${ }^{1,3}$ Defri Yona, ${ }^{1,2}$ Muhammad Arif Asadi, ${ }^{1,2}$ Rarasrum Dyah \\ Kasitowati, ${ }^{1,2}$ Citra Satrya Utama Dewi, ${ }^{1,2}$ Oktiyas Muzaky Lutfi, ${ }^{1,2}$ Andik Isdianto \\ ${ }^{1}$ Program Studi Ilmu Kelautan, Fakultas Perikanan dan Ilmu Kelautan, Universitas Brawijaya \\ ${ }^{2}$ Coastal Resilience and Climate Change Adaptation (CORECT) Research Group, Universitas Brawijaya \\ ${ }^{3}$ Marine Resources Exploration and Management (MEXMA) Research Group, Universitas Brawijaya \\ "Penulis korespondensi email: alviyantidian@ub.ac.id
}

(Received: 11 November 2020/Accepted: 22 Januari 2021/Published: 28 Januari 2021)

\begin{abstract}
Abstrak
TPI Sendang Biru berada di Kabupaten Malang memiliki potensi yang besar baik dalam bidang penyediaan pasokan ikan ataupun sarana prasarana penunjang lainnya. Pelabuhan perikanan tersebut dipersiapkan sebagai pusat pertumbuhan ekonomi perikanan di wilayah selatan Provinsi Jawa Timur. Pemerintah melalui Direktorat Jenderal Perikanan Tangkap Kementerian Kelautan dan Perikanan Tahun 2018 telah menyelesaikan relokasi pembangunan kios ikan berkonsep higienis pada wilayah tersebut untuk menunjang mutu hasil ikan dan harga jual ikan tetap tinggi. Sejalan dengan hal tersebut Pemerintah Propinsi Jawa Timur saat ini melakukan pengembangan jalur lintas selatan untuk mempermudah aksesbilitas. Namun, adanya wabah pandemi Covid-19 saat ini menyebabkan dampak yang besar pada berbagai bidang termasuk bidang perikanan. Hal tersebut menyebabkan bukan hanya minat beli masyrakat yang menurun, namun keterbatasan jalur distribusi produk juga menghambat transaksi jual-beli masyarakat. Berdasarkan hal tersebut perlu dilakukan pelatihan dan pembinaan manajemen pemasaran produk-produk perikanan di TPI Sendang Biru berbasis media jual-beli online. Metode edukasi yang dilakukan adalah seminar dengan topik strategi pemasaran digital berbasis media sosial dan workshop berbasis toko online atau marketplace. Melalui program ini diharapkan dapat menjadi salah satu langkah awal dalam menghadapi tantangan-tantangan baru dalam penanggulangan pemulihan ekonomi pasca pandemi Covid-19, serta dapat memperluas jejaring pemasaran para nelayan atau penjual ikan di wilayah tersebut bahkan hingga keadaan normal kembali.
\end{abstract}

Kata Kunci: pemasaran, marketplace, hasil perikanan, Covid-19

Abstract
TPI Sendang Biru, Malang Regency has great potentials in the field of fish supply or other
supporting infrastructure. This fishing port is being prepared as a fishery economic growth center
in the southern region of East Java Province. The government through the Directorate General
of Capture Fisheries of the Ministry of Marine Affairs and Fisheries has completed the relocation
of building a fish kiosk with a hygienic concept in the area to support the high quality of fish
products and the selling price of fish in 2018. According to this, the Provincial Government of
East Java is currently developing a southern route to facilitate accessibility. However, the current
Covid-19 pandemic has had a major impact on various fields including fisheries. This has caused
not only a decline in public buying interest, but limited product distribution channels have also
hampered people's buying and selling transactions. Based on this, it is necessary to conduct
training and coaching marketing management of fishery products at TPI Sendang Biru based on
online buying and selling media. The educational method used is seminars on the topic of digital
marketing strategies based on social media and workshop based on online stores or
marketplaces. This program is expected to be one of the first steps in facing new challenges in


overcoming the economic recovery after the Covid-19 pandemic, and can expand the marketing network of fishermen or fish sellers in the area even until conditions are returning to normal.

Keywords: marketing, marketplace, fishery products, Covid-19

\section{Pendahuluan}

Perkembangan ilmu pengetahuan dan teknologi saat ini terus menunjukan kemajuan pada berbagai bidang, termasuk dalam bidang ekonomi. Salah satunya, saat ini terdapat berbagai macam platform jual-beli secara online yang dikembangkan untuk menunjang kemudahan penjual dan pembeli dalam bertransaksi dan tentunya semakin meramaikan dunia perekonomian (Turban, King, Lee, Liang, \& Turban, 2015). Jenis-jenis platform jual-beli tersebut juga mendukung proses pemasaran atau jual-beli produk-produk perikanan. Melalui kemudahan yang ditawarkan tersebut dapat memberi dampak positif bagi pelaku usaha produk-produk perikanan seperti nelayan yang berada di wilayah terpencil untuk memasarkan produknya pada para konsumen di seluruh penjuru negeri ataupun mancanegara yang dapat mengakses platform jual-beli tersebut (Anandhita, 2013; Tekeba \& Mengistu, 2018).

TPI Sendang Biru yang berada di Jl. Dusun Sendang Biru Desa Tambak Rejo, Kecamatan Sumbermanjing Wetan, Kabupaten Malang merupakan salah satu pelabuhan yang dipersiapkan sebagai pusat pertumbuhan ekonomi perikanan di wilayah selatan Propinsi Jawa Timur, sejalan dengan persiapan sarana transportasi melalui pengembangan jalur lintas selatan yang sekarang sedang dikerjakan oleh Pemerintah Propinsi Jawa Timur (PIPP, 2020a). Pada tahun 2018, melalui Direktorat Jenderal Perikanan Tangkap Kementerian Kelautan dan Perikanan telah menyelesaikan relokasi pembangunan kios ikan higienis pada wilayah tersebut untuk menunjang mutu hasil ikan tetap tinggi hingga sampai ditangan konsumen, serta diharapkan pula dapat meningkatkan harga jual ikan yang semakin tinggi (PIPP, 2020b). Berdasarkan upaya-upaya perbaikan tersebut menunjukan TPI Sendang Biru memiliki potensi yang besar baik dalam bidang sarana prasarana ataupun penyediaan pasokan ikan.

Adanya pandemik Covid-19 pada awal tahun hingga saat ini menyebabkan dampak yang besar pada berbagai bidang, bukan hanya bidang kesehatan yang terdampak secara langsung, namun bidang ekonomi merupakan salah satu yang mengalami dampak besar baik skala nasional ataupun internasional. Kamar Dagang dan Indutri Jawa Timur (Kadin) memprediksi kinerja ekspor pada kuartal I/2020 bisa tergerus 0,25 - 0,40 \% akibat wabah Virus Corona atau Covid19, termasuk pada wilayah Jawa Timur (Liputan 6, 2020). Adanya berbagai kebijakan untuk menekan penularan Covid-19 seperti lockdown antar Negara ataupun PSBB (Pembatasan Sosial Berskala Besar) dalam negeri menyebabkan jalur distribusi pemasok bahan baku ataupun bahan pangan menjadi terhambat. Keadaan tersebut tentunya akan berdampak pada semua sektor termasuk pada sektor perikanan. Bukan hanya minat beli masyrakat yang menurun, namun keterbatasan jalur distribusi produk juga dapat menghambat transaksi jualbeli masyarakat.

Melemahnya kondisi perekonomian tentunya harus diikuti dengan strategi khusus untuk menghadapi tantangan-tantangan baru yang sebelumnya tidak terfikirkan. Berdasarkan hal tersebut guna menanggulangi dampak pandemik Covid-19 pada bidang perikanan, Program Studi Ilmu Kelautan melakukan kegiatan pengabdian masyarakat berupa pelatihan dan pembinaan manajemen pemasaran produk-produk perikanan pada penjual ikan di TPI Sendang Biru berbasis media jual-beli online. Selain sebagai upaya penanggulangan Covid-19 melalui pelatihan tersebut diharapkan dapat memperluas jejaring pemasaran para nelayan atau penjual ikan hingga keadaan normal kembali. Tujuan dari kegiatan pengabdian ini adalah untuk memberikan ketrampilan dasar dan pengetahuan baru mengenai kegiatan pemasaran produkproduk perikanan secara online terutama pada masa pandemi Covid-19. 


\section{Metode}

\subsection{Waktu dan Tempat Pelaksanaan}

Kegiatan pengabdian dilakukan pada tanggal 27 Oktober 2020. Lokasi pengabdian berada di TPI Sendang Biru, secara khusus bertempat di aula kantor P2SKP Pondokdadap, Kabupaten Malang. Wilayah ini merupakan salah satu pemasok produk ikan segar di wilayah Malang Raya (Kabupaten Malang, Kota Malang, dan Kota Batu). Lokasi pengabdian dapat dilihat pada Gambar 1. Target peserta dalam kegiatan ini yang pertama adalah anggota Kelompok Pengolah dan Pemasar (Poklahsar) Adikarya yaitu kelompok penjual ikan segar di Pasar Ikan Sendangbiru. Target peserta kedua adalah kelompok penjual kerupuk ikan Desa Pangkahkulon, Kecamatan Ujung Pangkah, Kabupaten Gresik.

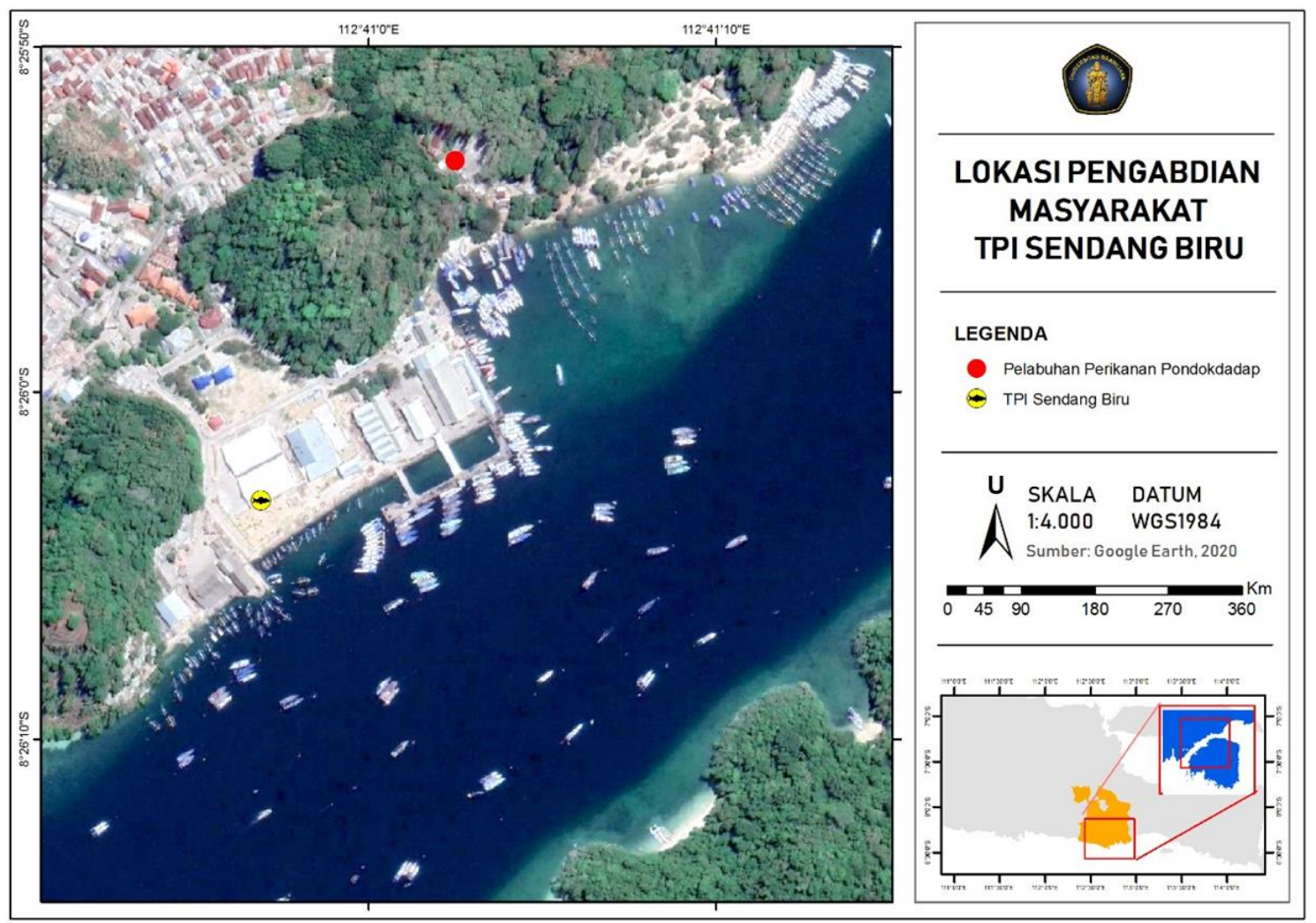

Gambar 1. Peta lokasi pengabdian

\subsection{Alat dan Bahan}

Kegiatan pengabdian kepada masyarakat terbagi menjadi dua aktivitas, yaitu (1) penyuluhan kepada anggota masyarakat penjual di TPI Sendang Biru dan (2) workshop kegiatan jual-beli produk-produk perikanan secara online. Kegiatan ini memerlukan beberapa perlengkapan pelatihan sebagai berikut (Tabel 1).

Tabel 1. Kelengkapan yang digunakan dalam kegiatan pengabdian

\begin{tabular}{lll}
\hline No & Bahan & Keperluan \\
\hline 1. & Modul & Petunjuk teknis pemasaran produk perikanan secara online \\
2. & ATK & Alat tulis-menulis \\
3. & Hp/Laptop & Simulasi kegiatan pemasaran produk perikanan secara online \\
4. & Kamera & Dokumentasi kegiatan \\
5. & Zoom cloud meetings & Aplikasi webinar \\
\hline
\end{tabular}




\subsection{Teknis Pelaksanaan}

Pelaksanaan kegiatan pengabdian dilakukan secara luring dan juga daring. Kegiatan pertama yaitu penyampaian materi tentang strategi pemasaran digital berbasis media sosial. Kegiatan ini dilakukan secara luring di lokasi pengabdian yaitu di aula kantor P2SKP Pondokdadap Kabupaten Malang. Selanjutnya penyampaian materi kedua dilakukan secara daring yaitu tentang penjelasan aplikasi marketplace Shoope serta kiat-kiat sukses dalam praktek jual-beli online. Selain penyampaian materi pada kegiatan kedua ini sekaligus dilakukan pratik langsung penggunaan aplikasi marketplace Shoope.

Kegiatan pengabdian dilakukan dengan menggunakan pendekatan Rural Partisipatory Apprasial (RPA). RPA yaitu pendekatan yang bertujuan untuk membuat rencana dan tindakan nyata untuk masa yang akan datang dengan meningkatkan dan menganalisis serta saling berbagi informasi yang memungkinkan masyarakat memahami kondisi kehidupan dan pengetahuan saat ini (Chambers, 1996). Melalui teknik pendekatan RPA diharapkan materi yang disampaikan dapat lebih mudah dipahami oleh peserta pelatihan. Pemberian materi kegiatan dilaksanakan oleh Tim pengabdian masyarakat dan narasumber eksternal. Konten yang diberikan adalah Teknik Pemasaran Produk-produk Perikanan: Berbasis Media Online yaitu pemasaran melalui media sosial dan marketplace.

Pemilihan metode ini dilatarbelakangi oleh kepraktisan dalam pelaksanaan, yang akan melibatkan masyarakat sebagai pelaku utama kegiatan pemasaran produk-produk perikanan tersebut. Beberapa platform media online yang akan dikenalkan pada masyarakat antaralain facebook, instagram bisnis, whatsApp bisnis, dan marketplace shopee. Selain memanfaatkan metode jual-beli online tersebut, akan dilakukan juga pembinaan pengembangan jejaring pemasaran melalui media WAG (WhatsApp Group). Data yang dibutuhkan dalam kegiatan tersebut antaralain berupa katalog yang berisi foto dan harga produk-produk perikanan yang akan dijual. Melalui kegiatan tersebut diharapkan dapat menambah alternatif dan mempermudah aktivitas jual-beli nelayan, meningkatkan nilai jual produk perikanan, dan tentunya dapat meningkatkan kesejahteraan masyarakat pesisir terutama nelayan.

\section{Hasil dan Pembahasan}

Kegiatan pengabdian masyarakat yang sudah dilakukan terbagi menjadi dua sesi, yaitu tahap persiapan dan pelaksanaan. Pada tahap persiapan dilakukan survey lokasi lapang dan wawancara dengan mitra. Selanjutnya pada tahap pelaksanaan dilakukan sosialisasi mengenai topik pengabdian yaitu strategi pemasaran digital berbasis media sosial dan juga marketplace.

\subsection{Persiapan}

Tahap persiapan dilakukan guna menunjang terlaksananya kegiatan dengan baik dan lancar. Pada tahap ini terdiri atas tiga tahap kegiatan yaitu kegiatan survey lokasi, rapat koordinasi dengan pihak-pihak terkait, serta pembuatan Whats App Group (WAG) peserta.

Survey lokasi dilakukan pada tanggal 15 Juni 2020 yaitu dengan melakukan peninjauan secara langsung ke lapangan pada kios-kios pasar ikan, tempat penurunan, dan pelelangan ikan TPI Sendangbiru (Gambar 2). Berdasarkan kegiatan tersebut diketahui bahwa animo atau daya beli masyarakat selama masa pandemi mengalami penurunan yang cukup signifikan dan menyebabkan lesunya pasar. Hal ini disebabkan oleh macetnya jalur distribusi perdagangan dari hulu ke hilir, seperti adanya permasalahan produksi hasil tangkapan yang berlebihan namun tidak dapat terserap oleh pasar sehingga mengakibatkan harga jual yang tidak stabil. Ketidakstabilan harga tersebut yaitu harga jual ditingkat nelayan jatuh namun harga beli sampai ditingkat konsumen terlalu tinggi (Firdaus, 2020). 


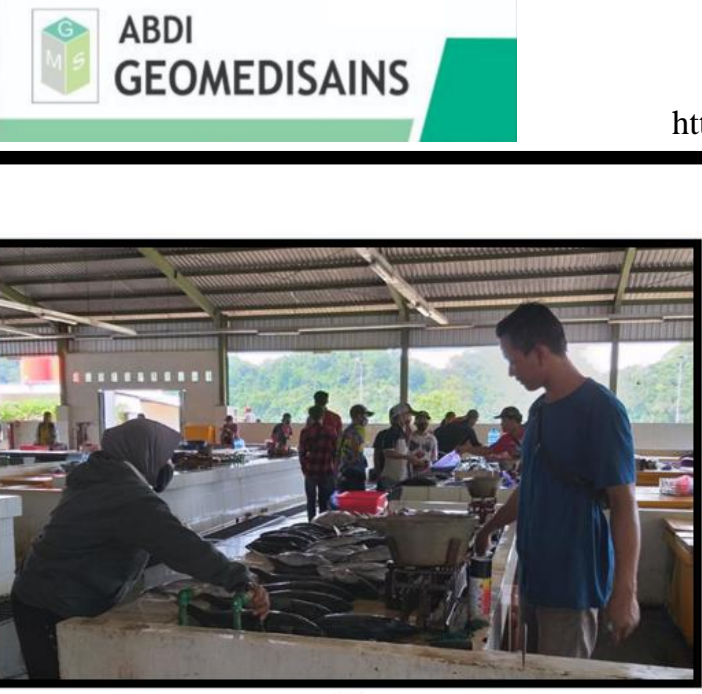

(a)

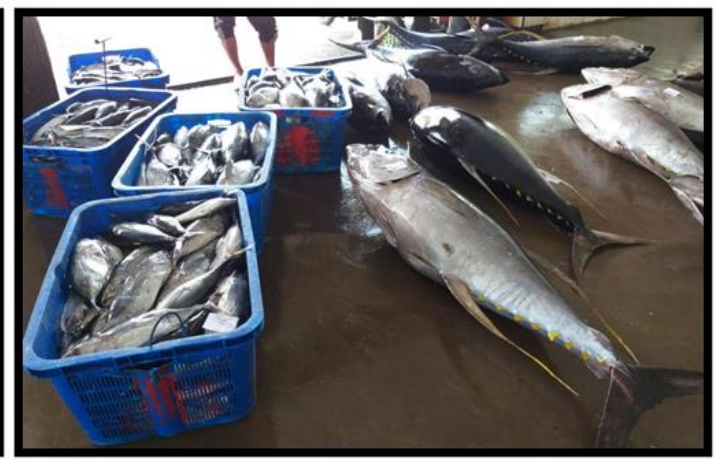

(b)

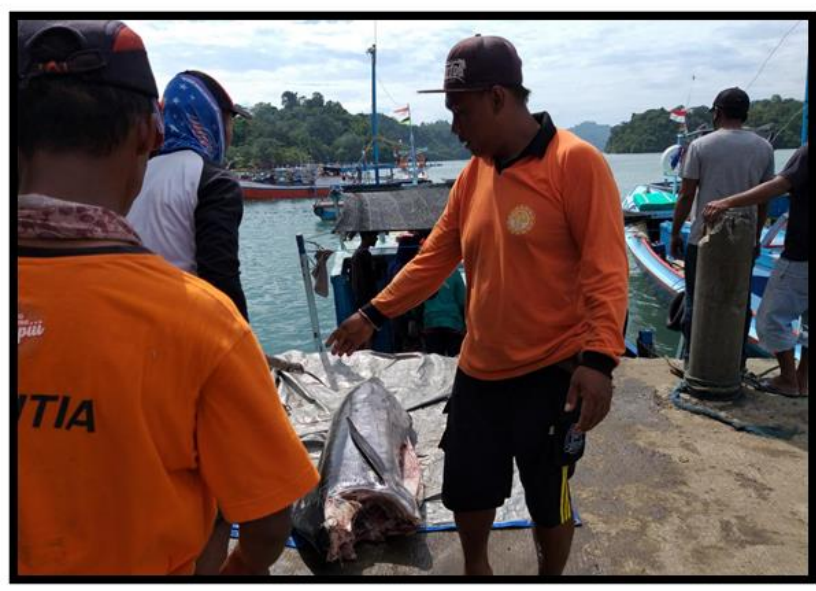

(c)

Gambar 2. Kegiatan survey lokasi di TPI Sendangbiru, a) Pasar ikan; b) Pelelangan ikan; c) Tempat penurunan ikan.

Lesunya pasar diakibatkan dari menurunnya permintaan para konsumen. Seperti yang terjadi pada Kota Tegal banyaknya industri perikanan dan juga restoran yang tutup menyebabkan harga jual ditingkat nelayan turun drastis (KKP, 2020). Selain itu, ditambah dengan kondisi PSBB (pembatasan sosial berskala besar) atau lockdown di beberapa lokasi menyebabkan lumpuhnya jalur distribusi hasil tangkapan ikan. Selama proses survey yang didampingi perwakilan Dinas Perikanan Kabupaten Malang, juga dilakukan rapat koordinasi dengan pengurus Poklahsar Adikarya yang mayoritas anggotanya adalah pedagang di pasar ikan Sendang biru (Gambar 3). Pengurus Poklahsar Adikarya membenarkan tentang kondisi yang dialami saat ini dan sangat antusias dengan rencana kegiatan pelatihan penjualan online guna mendukung revolusi industri 4.0 dan sebagai upaya adaptasi terhadap perubahan kondisi pedagangan akibat Covid-19.

Fakta yang terjadi di lapangan tersebut tentunya dapat menciptakan peluang dan tantangan tersediri dalam mengatasi permasalahan. Beberapa peluang dan juga tantangan yang terjadi selama masa pandemi ini adalah keterbukaan pasar domestik ditengah lesunya sektor ekspor, kesadaran ataupun tren dalam upaya meningkatkan imunitas melalui kegiatan gemar makan ikan, pemasaran secara daring dapat menjadi salah satu solusi ditengah kemacetan jalur distribusi konvensional, dan upaya memperkuat logistik ikan nasional. Selanjutnya bila pemerintah mampu menangkap momentum peluang dan tantangan dimasa pandemi Covid-19 ini, maka tentunya dapat menjadi tindakan mitigasi dalam upaya pemulihan ekonomi nasional (Firdaus, 2020). 


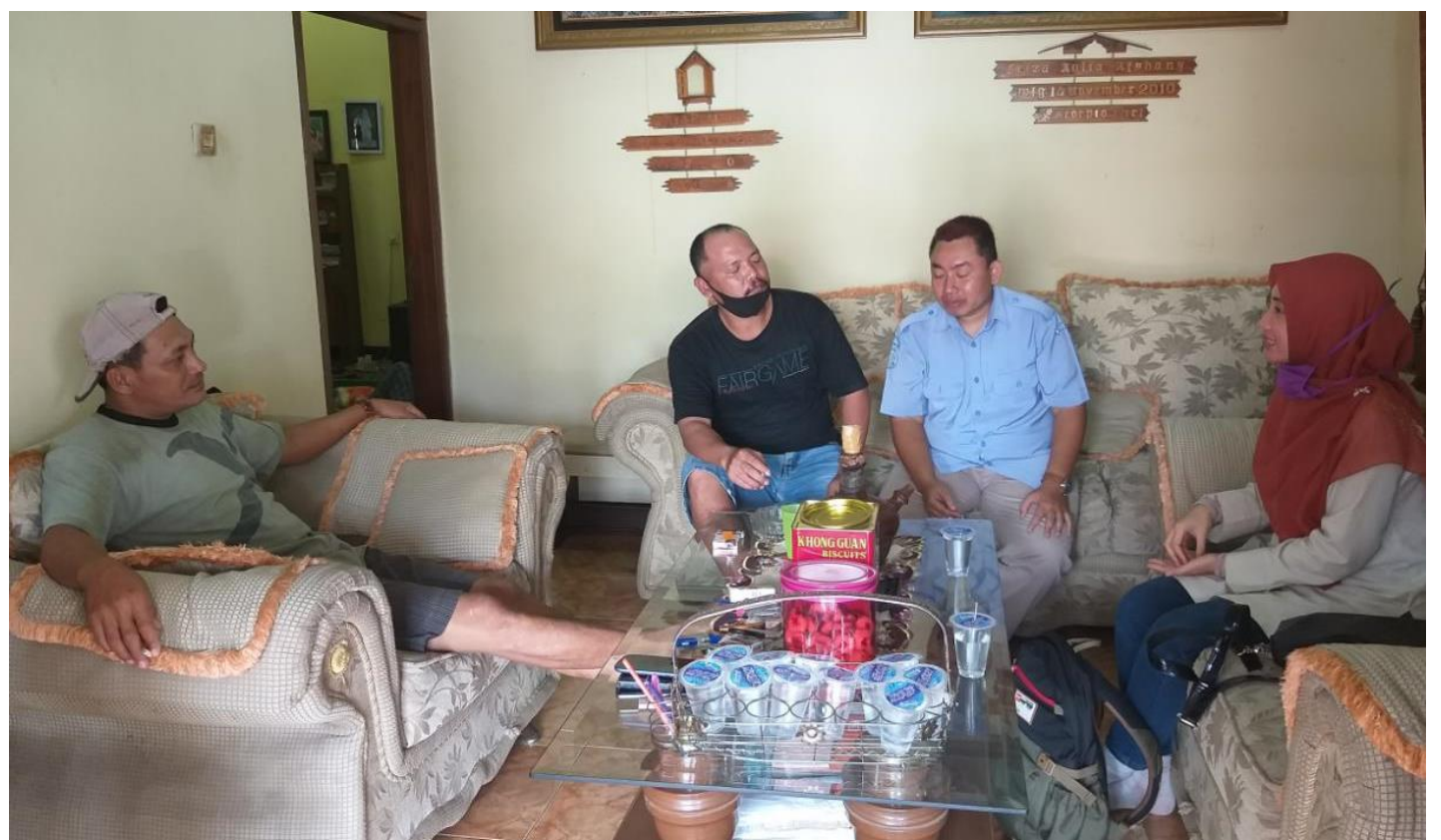

Gambar 3. Kegiatan rapat koordinasi dengan pengurus Poklahsar Adikarya dan perwakilan pendamping Dinas Perikanan Kabupaten Malang.

\subsection{Pelaksanaan}

Kegaiatan pengabdian masyarakat dilakukan pada tanggal 27 Oktober 2020. Kegiatan ini dilakukan secara daring dan juga luring. Kegiatan luring yaitu tim pengabdian masyarakat melakukan kunjungan secara langsung bertemu dengan masyarakat peserta pelatihan dan mengatur teknis kegiatan. Tim pengabdian berangkat dari Fakultas Perikanan dan Ilmu Kelautan pada hari pelaksanaan sekitar jam 06:00 pagi dan sampai pada lokasi kegiatan sekitar pukul 09:00 WIB. Total jumlah peserta yang hadir pada kegiatan luring sebanyak 10 peserta perwakilan pedagang dari Paguyuban Poklahsar Adikarya Sendang Biru. Sedangkan peserta yang mengikuti kegiatan secara daring mencapai 34 orang yang berasal dari berbagai UKM terutama adalah UKM Kerupuk Ikan Desa Pangkahkulon Kecamatan Ujung Pangkah Kabupaten Gresik.

Kegiatan pelatihan penjualan online dilakukan secara daring dan juga luring. Peserta luring adalah anggota dari Poklahsar Adikarya, sedangkan peserta daring adalah kelompok-kelompok UKM dari berbagai daerah salah satunya kelompok UKM Kerupuk ikan daerah Ujung pangkah Kabupaten Gresik. Kelompok UKM kerupuk ikan tersebut juga merupakan salah satu kelompok UKM binaan FPIK. Sebelum hari-H kegiatan seluruh peserta dikumpulkan dalam WAG sebagai wadah koordinasi dalam memberikan arahan dan informasi-informasi terkait kegiatan yang akan dilaksanakan. Melalui kegiatan ini diharapkan peserta akan lebih siap pada saat menerima informasi yang akan disampaikan pada sesi penyampaian materi ataupun praktik.

Kegiatan pengabdian masyarakat ini diawali dengan pemberian sambutan dari Kaprodi Ilmu Kelautan FPIK UB sebagai salah satu tim pengabdian masyarakat. Selanjutnya penyampaian sambutan kedua oleh Kepala Seksi Pelayanan Pengolahan Hasil Perikanan Dinas Perikanan Kabupaten Malang Ir. Rudy Kurnianto, MM. (Gambar 4). Pada sesi penyampaian materi, diisi oleh dua narasumber yang membahas tentang strategi pemasaran berbasis sosial media dari tim pengabdian masyarakat FPIK. Selanjutnya pada penyampaian materi kedua diisi dengan materi dan praktik tentang strategi pemasaran dan penjualan online berbasis marketplace Shopee. Sesi penyampaian materi dan diskusi berlangsung kurang lebih selama dua jam. 

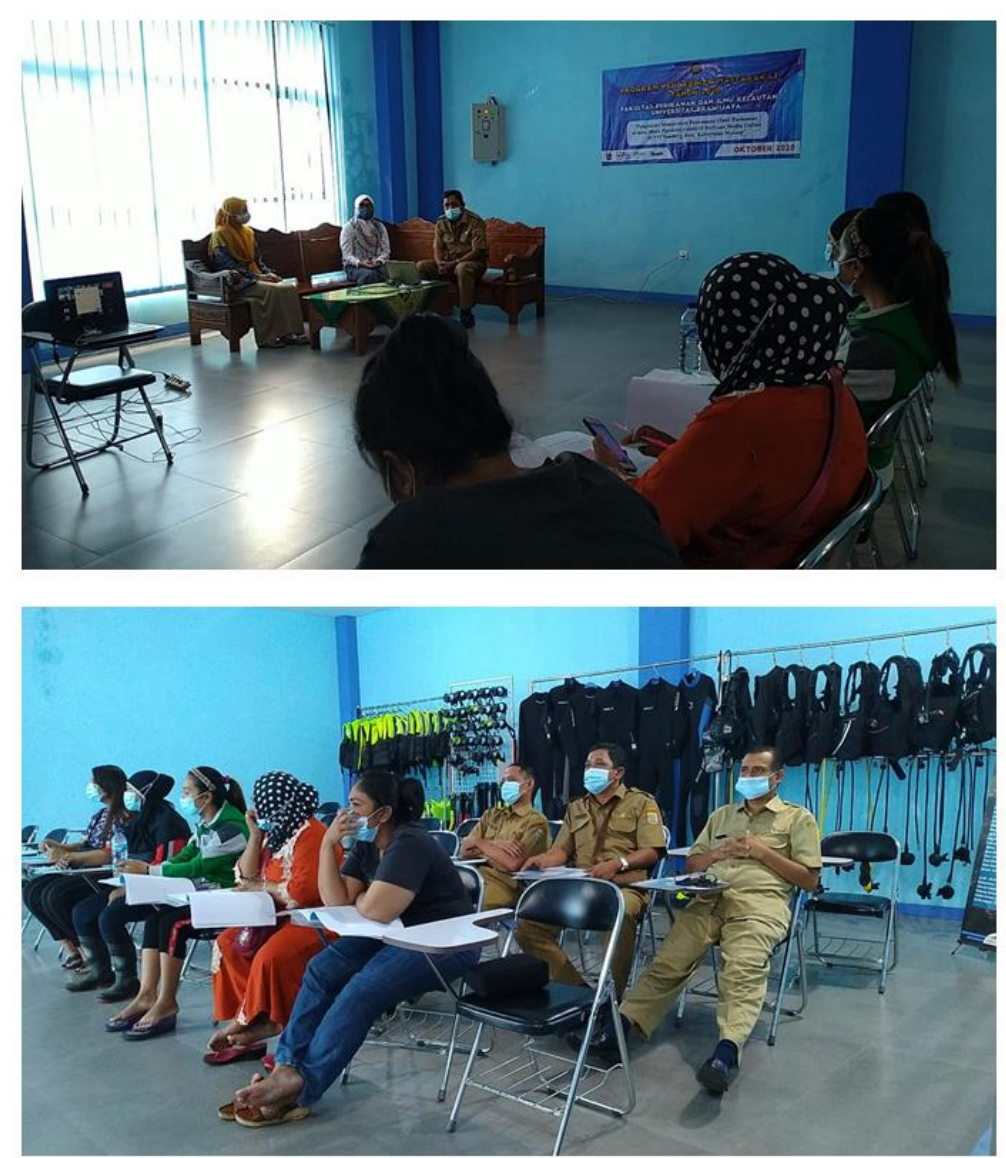

Gambar 4. Kegiatan sosialisasi secara luring dari kantor P2SKP Pondokdadap Malang.

Pada kegiatan penyampaian materi salah satunya diberikan penjelasan tentang strategi pemasaran berbasis media sosial. Hal ini bertujuan agar masyarakat bisa menyadari bahwa penjualan online dapat dilakukan dengan mudah dan lebih bersahabat karena media sosial seperti WA, facebook, ataupun instagram adalah jenis-jenis media sosial yang sudah umum dan sering digunakan oleh banyak kalangan masyarakat. Sehingga melalui pengoptimalan jenis-jenis media sosial tersebut dapat memudahkan masyarakat dalam memasarkan produk-produk dagangannya.

Membuat toko online di media sosial memiliki berbagai keuntungan karena kepraktisannya, mudah, dan gratis (Harahap \& Aminah, 2018). Penggunaan media sosial untuk pemasaran dapat memperbesar peluang jual-beli karena dapat mendekatkan penjual dengan calon-calon pembeli yang sebelumnya sudah dikenal atau masih belum kenal satu sama lain. Selain itu melalui pemasaran berbasis media sosial juga dapat menjangkau cakupan area calon pembeli yang lebih luas (Bucko, Kakalejčík, Ferencová, \& Wright, 2018).

Selain menggunakan media sosial, perdagangan elektronik (e-commerce) juga bisa dilakukan melalui toko online seperti Shopee. Jenis toko online seperti Shopee termasuk jenis customer to customer (C2C) yaitu memfasilitasi untuk mempromosikan produk dan melayani transaksi uang secara online (Harahap \& Aminah, 2018). Hasil data Badan Pusat Statistik (BPS, 2020) memperlihatkan peningkatan penjualan online yang signifikan selama masa pandemi Covid-19 (Badan Pusat Statistik, 2020). Kompas merangkum beberapa faktor yang melatarbelakangi hal tersebut terjadi diantaranya adalah kondisi masyarakat yang dituntut untuk menghindari keramaian sehingga untuk memenuhi kebutuhannya masyarakat akan memilih untuk belanja secara online dari rumah masing-masing (Catriana, 2020). Kondisi seperti ini juga tidak disia-siakan oleh pengusaha e-commerce dengan memberikan berbagai promo-promo menarik selama masa Pandemi Covid-19. Pada sesi ini selain dilakukan pemaparan materi dari narasumber 
juga dilakukan praktik penjualan online menggunakan akun Shopee masing-masing peserta (Gambar 5).

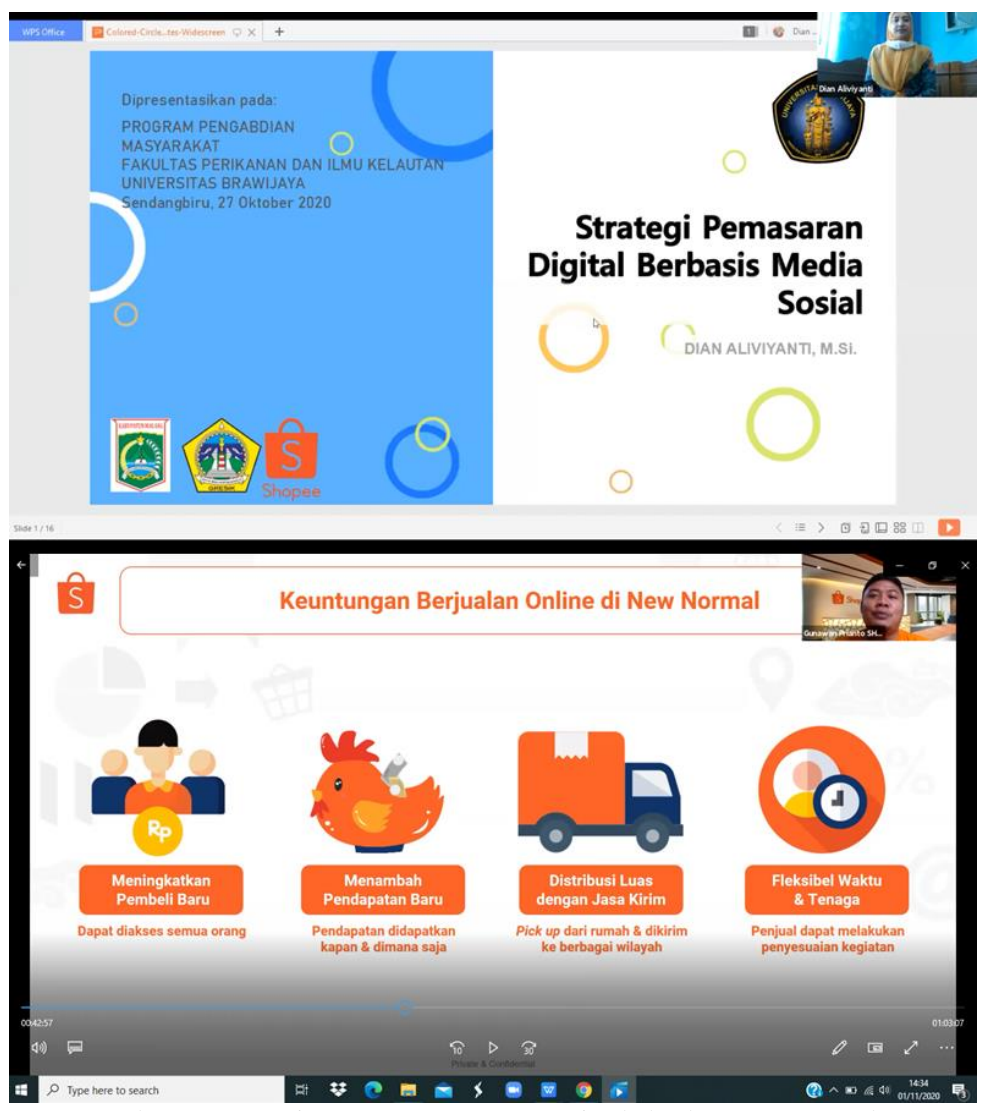

Gambar 5. Sesi pemaparan materi oleh dua narasumber.

Keterbukaan informasi saat ini yang berkembang dengan pesat dapat mendukung untuk kemajuan perekonomian secara pesat ataupun sebagai salah satu upaya mitigasi pemulihan ekonomi dimasa Pandemi Covid-19. Namun untuk mewujudkan kegiatan tersebut perlu diimbangi dengan kemampuan sumber daya manusia yang terampil dan tangguh menghadapi perubahan lingkungan. Kegiatan pengabdian masyarakat yang sudah dilakukan pada komunitas pedagang ikan dan olahannya ini menjadi awal dari berbagai strategi untuk meningkatkan kesejahteraan nelayan secara umum.

\section{Simpulan}

Kegiatan sosialisasi dan pembinaan manajemen hasil perikanan sangat dibutuhkan oleh masyarakat pesisir terutama pada era digital saat ini, serta sebagai upaya mitigasi ketahanan ekonomi pada masa pandemi Covid-19. Melalui kegiatan tersebut dapat diketahui tingkat pemahaman dan antusiasme masyarakat terhadap materi-materi yang disampaikan. Kegiatan pemasaran dan penjualan online dapat dilakukan dengan cara yang mudah dan sederhana melalui sosial media seperti whatsApp (WA), facebook, dan instagram, serta marketplace. Berbagai keuntungan yang diperoleh melalui pemasaran online yaitu memiliki peluang lebih dikenal oleh masyarakat luas, dengan kemudahan distribusi, dan fleksibilitas waktu dan tenaga, dan tentunya dapat menambah pendapatan bagi pengusaha.

Guna mendukung implementasi yang lebih mendalam lagi perlu dilakukan kegiatan pendampingan tambahan seperti pembinaan mengenai teknik pengawetan dan pengemasan ikan segar atau produk olahannya yang ramah lingkungan. Sosialisasi dan pemetaan jalur distribusi pemasaran dari hulu ke hilir yang praktis dan efisien. Serta perumusan dan pengenalan metode pembayaran secara online untuk memutus budaya hutang pada nelayan. 


\section{Persantunan}

Ucapan terima kasih ditujukan kepada Universitas Brawijaya atas bantuan dana pengabdian masyarakat melalui Dana Pendapatan Negara Bukan Pajak (PNBP) 2020. Badan Penelitian dan Pengabdian Masyarakat Faskultas Perikanan dan Ilmu Kelautan (FPIK) UB dan semua pihak yang terlibat dalam kegiatan pengabdian ini.

\section{Referensi}

Anandhita, V. H. (2013). Studi Pemilihan Layanan Jasa Pengiriman Oleh Pelaku Bisnis Online Sebagai Sarana Distribusi Produk Menggunakan Strategi Marketing Mix di DKI Jakarta. Jurnal Penelitian Pos dan Informatika, 3(1), 1-18.

Badan Pusat Statistik. (2020). Tinjauan Big Data terhadap Dampak Covid-19. Jakarta: BPS Katalog.

Bucko, J., Kakalejčík, L., Ferencová, M., \& Wright, L. T. (2018). Online shopping: Factors that affect consumer purchasing behaviour. Cogent Business \& Management, 5(1), 1535751. https://doi.org/10.1080/23311975.2018.1535751

Catriana, E. (2020). Aktivitas Belanja Online Meningkat Drastis, Ini Sebabnya Halaman all. Kompas.com. Diakses January 16, 2021, dari https://money.kompas.com/read/2020/10/27/135847026/aktivitas-belanja-onlinemeningkat-drastis-ini-sebabnya?page $=$ all.

Chambers, R. (1996). PRA (Participatory Rural Appraisal) Memahami Desa Secara Partisipatif. Yogyakarta: Kanisius.

Firdaus, I. (2020). Pengelolaan Perikanan di Masa Pandemi Covid-19. Presented at the ISPIKANI TALK. Diakses dari https://kkp.go.id/an-component/media/upload-gambarpendukung/DitJaskel/publikasi-materi-2/ispikani1/Ichsan\%20Firdaus_Pengelolaan\%20Perikanan\%20Era\%20Covid-1.pdf

Harahap, D. A., \& Aminah, D. (2018). Perilaku belanja Online di Indonesia: Studi Kasus. JRMSI - Jurnal Riset Manajemen Sains Indonesia, 9(2), 193-213. https://doi.org/10.21009/JRMSI

KKP. (2020). Riset Analisis Kebijakan Pemenfaatan Sumber Daya Perikanan Tangkap dalam Pendemic Covid-19: FGD Pola Pemanfaatan Sumber Daya Perikanan dalam Masa Pandemi Covid-19. Diakses January 16, 2021, dari https://kkp.go.id/brsdm/sosek/artikel/22843-risetanalisis-kebijakan-pemanfaatan-sumber-daya-perikanan-tangkap-dalam-pandemic-covid19

Liputan 6. (2020). Ekonomi Jatim Bakal Turun pada Kuartal I 2020 Imbas Virus CoronaSurabaya. Diakses May 28, 2020, dari https://surabaya.liputan6.com/read/4173000/ekonomi-jatim-bakal-turun-pada-kuartal-i2020-imbas-virus-corona

PIPP. (2020a). Pusat Informasi Pelabuhan Perikanan | Profil Pelabuhan. Diakses May 28, 2020, dari http://pipp.djpt.kkp.go.id/profil_pelabuhan/1338/informasi

PIPP. (2020b). Pusat Informasi Pelabuhan Perikanan | Menuju Peresmian, Kementerian Kelautan dan Perikanan mengadakan Sosialisasi Kios Ikan Higienis di Pelabuhan Perikanan Pondok Dadap. Diakses May 28, 2020, dari http://pipp.djpt.kkp.go.id/detail_berita/9535

Tekeba, K., \& Mengistu, E. W. (2018). Assessment of Service Delivery Practice and Customer Satisfaction of Micro Finance Institutions: (The Case of ACSI, Gondar). Global Journal of Management and Business Research: C Finance, 18(4), 1-13.

Turban, E., King, D., Lee, J. K., Liang, T.-P., \& Turban, D. C. (2015). Electronic Commerce: A Managerial and Social Networks Perspective. Cham: Springer International Publishing 